\title{
Hybrid technology used for the production of individual medical implants from titanium alloys
}

\author{
Technologia hybrydowa w produkcji indywidualnych \\ implantów medycznych ze stopów tytanu
}

\section{ANDRZEJ STYCZYŃSKI \\ KASPER FOGEL \\ WŁODZIMIERZ KOŁODZIEJ \\ JAROSŁAW WRÓBLEWSKI *}

The effect of R\&D works covered by the project entitled „Designing the surface structures of individual medical implants, produced in hybrid technology using a laser head", implemented as part of the Smart Growth Operational Programme No. POIR.01.01.01. The technology of waste machning of implants from medical titanium alloys has been improved and the technology of laser surface modification of the implant has been developed.

KEYWORDS: cutting tools, machining of titanium, productivity, implants

Two goals have been achieved. The first was to increase the machining efficiency of titanium alloys thanks to the design of new cutting tools and new machining methods using: a 70 bar coolant, high cutting forces, a rigid system (suitable for slender items) and optimized tool paths. As a result, the processing efficiency increased more than 10 times, and the technical cost of manufacturing has also decreased. The second goal was to modify the surface of the implant using a laser, which resulted in a greater biocompatibility (by $5 \div 10 \%$ better osseointegration) compared to the unmodified reference surface.

\section{Optimization of milling technology for titanium alloys}

A team of specialists from the PAFANA company has comprehensively developed a new technology for efficient treatment of medical devices from titanium alloys, which can also be used in the production of other, complicated details from these materials, e.g. aviation parts. As part of the project, research and development of new designs of monolithic mandrel mills were carried out.

\section{n Blade material. Complete implant processing required} the use of cutters with diameters $\varnothing 3 \div 16 \mathrm{~mm}$. The cutter material was selected based on the analysis of the state of the art, recommendations of cemented carbide manufacturers, as well as own tests and trials. It was decided on the so-called ultrafine carbides [1]. Physical properties of one of the carbides used are given in the tab. I.

\footnotetext{
* Mgr inż. Andrzej Styczyński (andrzej.styczyński@pafana.pl), mgr inż. Kasper Fogel (k.fogel@pafana.pl), mgr inż. Włodzimierz Kołodziej (w.kolodziej@pafana.pl), mgr inż. Jarosław Wróblewski (j.wroblewski@pafana.pl) - Pabianicka Fabryka Narzędzi "PAFANA" S.A.
}

TABLE I. Physical properties of exemplary ultrafine cemented carbide

\begin{tabular}{|c|c|c|c|c|}
\hline $\begin{array}{c}\text { Grain } \\
\text { size, } \\
\mu \mathrm{m}\end{array}$ & $\begin{array}{c}\text { Density, } \\
\mathrm{g} / \mathrm{cm}^{3}\end{array}$ & $\begin{array}{c}\text { Hardness } \\
\text { HV30 }\end{array}$ & $\begin{array}{c}\text { Hardness } \\
\text { HRA }\end{array}$ & $\begin{array}{c}\text { Application } \\
\text { group } \\
\text { according } \\
\text { to ISO }\end{array}$ \\
\hline $0,5-0,8$ & 14,38 & 1600 & 91,9 & K20-K40 \\
\hline
\end{tabular}

- Milling geometry. Based on the experience gathered at PAFANA during the implementation of implants, guidelines for the construction of monolithic carbide milling cutters intended for the machining of titanium alloys were developed (tab. II).

TABLE II. Geometry of monolithic milling cutters for the machining of titanium alloys - design recommendations

\begin{tabular}{|l|c|}
\hline Geometric size of cutters & $\begin{array}{c}\text { Recommended } \\
\text { values }\end{array}$ \\
\hline Tilt angle of the cutting edge & $30^{\circ}-45^{\circ}$ \\
\hline Peripheral attack angle & $10^{\circ}-16^{\circ}$ \\
\hline 1. peripheral contact angle & $8^{\circ}-13^{\circ}$ \\
\hline 2. peripheral contact angle & $18^{\circ}-25^{\circ}$ \\
\hline 1. top contact angle & $8^{\circ}-13^{\circ}$ \\
\hline 2. top contact angle & $18^{\circ}-25^{\circ}$ \\
\hline $\begin{array}{l}\text { Radius of rounding of the cutting } \\
\text { edge }\end{array}$ & $8-12 \mu \mathrm{m}$ \\
\hline
\end{tabular}

- Protective coatings. The monolithic milling cutters for the machining of titanium alloys should have coatings reducing the coefficient of friction between the blade and the chip, which are resistant to abrasion and high temperature [2]. Two types of high quality PVD coatings were used on cutters for processing implants, in which the AITiN or AICrN layer - with high ductility and hardness - is protected with a top layer of nanocomposite (CrAISiN) with very high abrasion resistance.

- Cooling of the machining zone. The machining of titanium alloys should be carried out with abundant coolant 
supply. At the same time, internal coolant supply was applied - under high pressure (70 bar) - and external $(7 \div 10$ bar). Mills with central (axial) and radial cooling holes (with three holes on the circumference) were tested. In the case of surface treatment of curvilinear surfaces (implants), monolithic milling cutters mainly work with front edges and radial corners. As shown by the tests, the best solution is then to use one central hole supplying high-pressure coolant directly to the treatment zone and additional, external coolant supply. Mills with small diameters (ø3 and ø6) worked with curtain cooling (70 bar).

- Making a series of monolithic mandrel cutters. After the trial series and their testing, production series of cutters with diameters $\varnothing 3 \div 16 \mathrm{~mm}$ (fig. 1) were produced. For this purpose, a Da Vinci 1300 hybrid laser machining center from CB Ferrari was used (fig. 2).

The Da Vinci 1300 laser, which is a combination of a fiveaxis milling center and a laser head that performs machining in five axes, allows machining and laser machining to be performed in one workpiece fixture and a finished medical implant with a modified surface structure. The machine tool has a very rigid structure (including a cast iron body with cement filling) and good dynamic parameters. Due to the high power of the $28 \mathrm{~kW}$ electro-spindle (constant in the range of $4200 \div 20,000 \mathrm{rpm}$ ) and considerable revolutions (at high torque), it is possible to efficiently process machining of titanium alloys.

A very important feature of the machine is the function of internal feeding through a spindle electro-fluid at 70 bar. Basic, important from the point of view of the implementation of the discussed project, technical data of the Laser Da Vinci 1300 center are:

- speed of feed motion in the $X, Y, Z$ axes: $0 \div 30 \mathrm{~m} / \mathrm{min}$,

- positioning accuracy (VDI/DGQ 3441) in the $X, Y, Z$ axes: $0.01 \mathrm{~mm}$,

- motor spindle motor power: $28 \mathrm{~kW}$ (constant over a wide speed range),

- spindle torque: $63 \mathrm{Nm}$ at $4200 \mathrm{rpm}$,

- maximum spindle speed: 20,000 rpm.

The center is equipped with two laser heads: FLS352 and LFS300. They can be used for: drilling holes (with a minimum diameter of $0.05 \mathrm{~mm}$ ), five-axis welding to a depth of $0.25 \div 2.5 \mathrm{~mm}$ and five-axis welding (minimum diameter of the cutting radius $-\varnothing 0.05 \mathrm{~mm}$, maximum cutting thickness $5 \mathrm{~mm})$.

\section{Characteristics of the machining system and} optimization of tool paths in the machining program

As part of the research, instrumentation was designed and tested for slender workpieces, such as the mandibular implant. The machining strategy was adopted in three linear liquid axes $(X, Y, Z)$, and the positioning for individual treatments took place in the fourth rotary axis $C$. The fifth rotary axis $B$ was used to support the blank in a specially designed device, increasing the stiffness of the machining system.

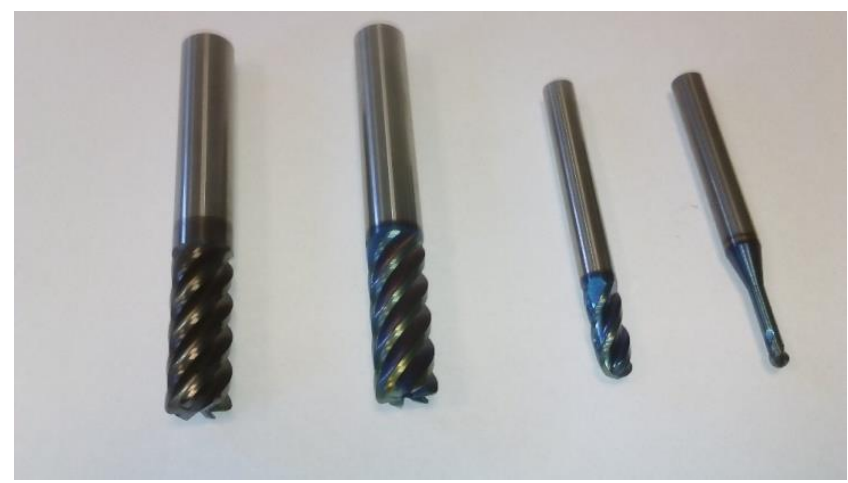

Fig. 1. Monolithic end mills made at PAFANA

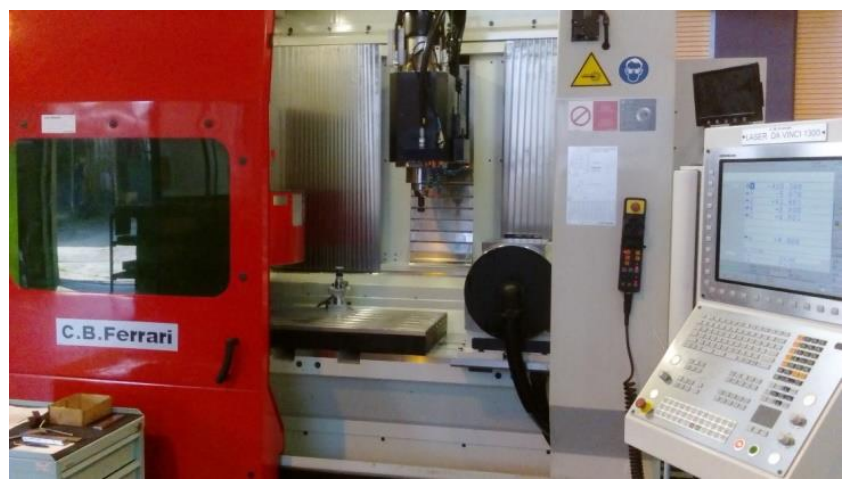

Fig. 2. View of the Da Vinci 1300 hybrid center

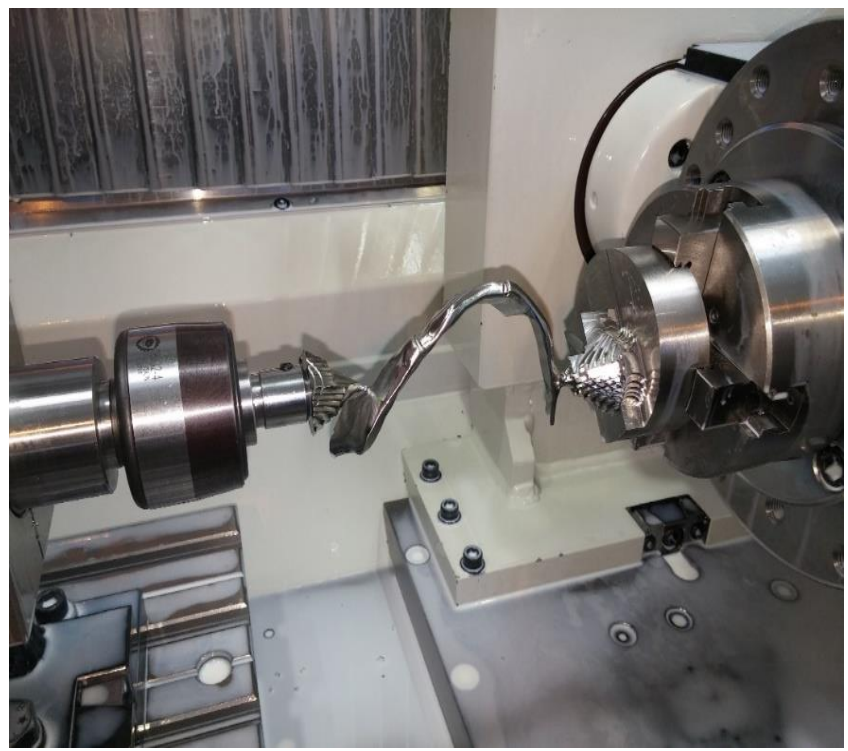

Fig. 3. Machining system with the device and object (finishing)
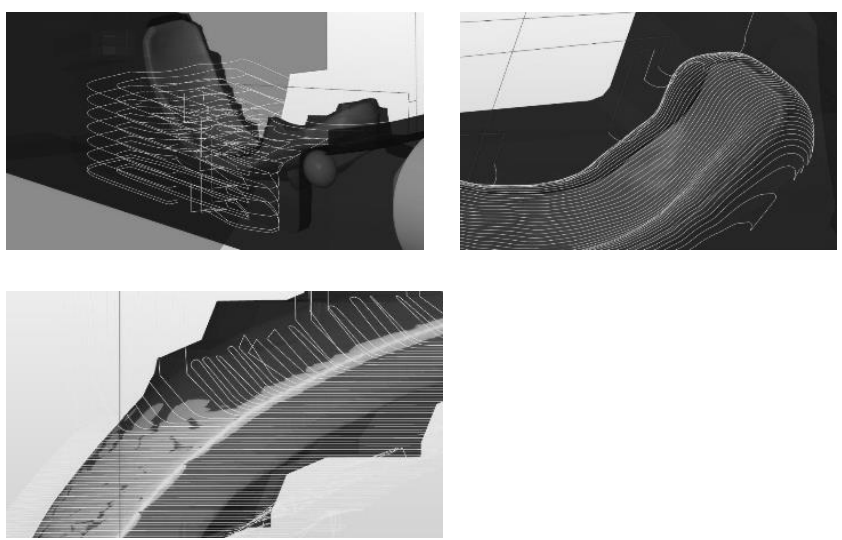

Fig. 4. Three machining strategies used in mandibular implant technology 
The workpiece was mounted on a tilting and turning table through a turning latch and support with a tailstock in a rotating glue with a cylindrical seat with a clamp (fig. 3 ). The blank has been made in the semi-finished product in accordance with the geometry of the device's socket. In order to improve the attachment, a special insert for the turning system was also made. The described mounting method provided the desired rigidity of the handle-objecttool system during machining, which translated into the achievement of the required quality of the model.

The waste machining technology was developed using CAM hyperMill software with a postprocessor for the Laser Da Vinci 1300 machine. This enabled continuous machine operation and at the same time allowed to minimize cycle times. The tool paths in the part program are designed according to three strategies (fig. 4). They were:

- rough machining of blank (fig. $4 a$ ) - paths run parallel to the outline of the model with respect to the $X$ and $Y$ axes, going down with respect to the $Z$ axis;
- shaping and finishing work (fig. 4b) - paths run with a zigzag at a selected angle with respect to the $X$ and $Y$ axes, sinking in relation to the $Z$ axis;

- shaping and finishing work with constant $Z$ infeed (fig. $4 c)$ - tool paths generated on steep areas with a constant step in the $Z$ axis; $X$ and $Y$ axes moving in a spiral or zigzag.

Research was carried out to increase the machining efficiency, while maintaining the surface roughness of the finished $\mathrm{Ra}$ implant at the level of $\leq 2.5 \mu \mathrm{m}$. In the case of roughing with a $\varnothing 10 \mathrm{~mm}$ diameter cutter from PAFANA, the volumetric yield of the machining increased four times - to $3.1 \mathrm{~cm}^{3} / \mathrm{min}$

\section{Evaluation of process effectiveness and the result of technology optimization}

Thanks to the optimization of the technology, extremely favorable results have been achieved in the form of shortening the processing time and $10 \div 12$-fold reduction of the technical production cost.

TABLE III. Summary of processing times, productivity and manufacturing costs for a selected implant (own research)

\begin{tabular}{|c|c|c|c|c|c|c|}
\hline $\begin{array}{c}\text { Number } \\
\text { of sample }\end{array}$ & Sample details & $\begin{array}{l}\text { Main } \\
\text { time, } \\
\text { min }\end{array}$ & $\begin{array}{l}\text { Mean efficiency, } \\
\mathrm{cm}^{3} / \mathrm{min}\end{array}$ & $\begin{array}{l}\text { Machining cost, } \\
\text { zloty per piece }\end{array}$ & Tool cost, zloty per piece & $\begin{array}{l}\text { Operational TKW, } \\
\text { zloty per piece }\end{array}$ \\
\hline 0 & $\begin{array}{l}\text { IMPLANT1_Program 0 } \\
\text { Frezy konkurencji A: } \varnothing 12 \mathrm{r} 2\left(T_{\mathrm{c}}=240\right. \\
\mathrm{min}), \varnothing 6 \mathrm{r} 3\left(T_{\mathrm{c}}=80 \mathrm{~min}\right), \varnothing 3 \mathrm{r} 1.5\left(T_{\mathrm{c}}=\right. \\
180 \mathrm{~min})\end{array}$ & 1376 & 0,82 & 4823,01 & 373,59 & 5955,43 \\
\hline 1 & $\begin{array}{l}\text { IMPLANT1_Program } 2 \\
\text { Frezy konkurencji B: } \varnothing 12 \mathrm{r} 2\left(T_{\mathrm{c}}=240\right. \\
\mathrm{min}), \varnothing 8 \mathrm{r} 4\left(T_{\mathrm{c}}=180 \mathrm{~min}\right), \varnothing 6 \mathrm{r} 3\left(T_{\mathrm{c}}=\right. \\
80 \mathrm{~min}), \varnothing 3 \mathrm{r} 1.5\left(T_{\mathrm{c}}=180 \mathrm{~min}\right), \varnothing 6 \mathrm{r} 1 \\
\left(T_{\mathrm{c}}=120 \mathrm{~min}\right)\end{array}$ & 130 & 2,25 & 569,81 & 230,75 & 890,21 \\
\hline 2 & $\begin{array}{l}\text { IMPLANT1_Program } 5 \\
\text { IMFREZ } 6\left(T_{\mathrm{c}}=120 \mathrm{~min}\right) \text { i IMREZ } 8\left(T_{\mathrm{c}}\right. \\
=150 \mathrm{~min}) \mathrm{z} \text { powłoką ALNOVA }\end{array}$ & 101 & 2,93 & 445,52 & 124,20 & 639,81 \\
\hline 3 & $\begin{array}{l}\text { IMPLANT1_Program } 5 \\
\text { IMFREZ } 6\left(T_{\mathrm{c}}=160 \mathrm{~min}\right) \text { i IMREZ } 8\left(T_{\mathrm{c}}\right. \\
=150 \mathrm{~min}) \mathrm{z} \text { powłoką TRIPLE Cr }\end{array}$ & 101 & 2,93 & 442,33 & 98,22 & 610,14 \\
\hline
\end{tabular}

The cost model adopted for the PAFANA economic model was presented during the IV, V and VI School of Machining.

During the tests, three forms of blade wear were observed in accordance with ISO 8688: local VB3 clash, $\mathrm{CH} 3$ localized chip and CF catastrophic wear.

Five machining variants were developed from a rectangular prismatic material measuring $32 \times 32 \times 140 \mathrm{~mm}$, differing in machining parameters, tooling path strategy, path spacing and cooling method. The cutting was carried out to achieve a consumption of VB3 $=0.3 \mathrm{~mm}, \mathrm{CH}_{3}$ or $\mathrm{CF}$ or until an unacceptable surface quality ( $R a$ above $2.5 \mu \mathrm{m})$ was obtained. In subsequent tests, solid carbide cutters from different manufacturers were tested (the titanium alloying parameters recommended by them were used) and milling cutters designed and made at PAFANA. Technological effects were subjected to technical analysis of the cost of manufacturing (TKW) operations, divided into machine and tooling costs (tab. III).

Our own tests showed that in relation to the initial state (sample 0) almost 14 times shortening of the machining time (main time) and almost 10-fold reduction of the CTC of the operation were achieved.

\section{Modification of the implant surface}

In order to achieve a better osseointegration of the implant with the bone in the area of the anastomosis, the implant's surface was modified by the laser beam. After the specific action of the beam, a structure was obtained that provides a good environment for the adhesion and growth of bone cells (this was tested in laboratories of the Bionanopark in Lodz and will be published in medical journals).

The machining was carried out on the Laser Da Vinci 1300 milling center using laser heads LFS (fiber laser) and FLS (flash lamp laser - pulsed laser). Established control

generates high-energy, pulsed laser beams, and at the place of their interaction, the material from the implant surface is immediately evaporated or splattered, creating a fouling microstructure. The laser beam focused around the implant surface changes the topography of the surface on which the mesh of blind holes with a diameter of approx. $\varnothing 0.05 \mathrm{~mm}$ is formed (fig. 5).
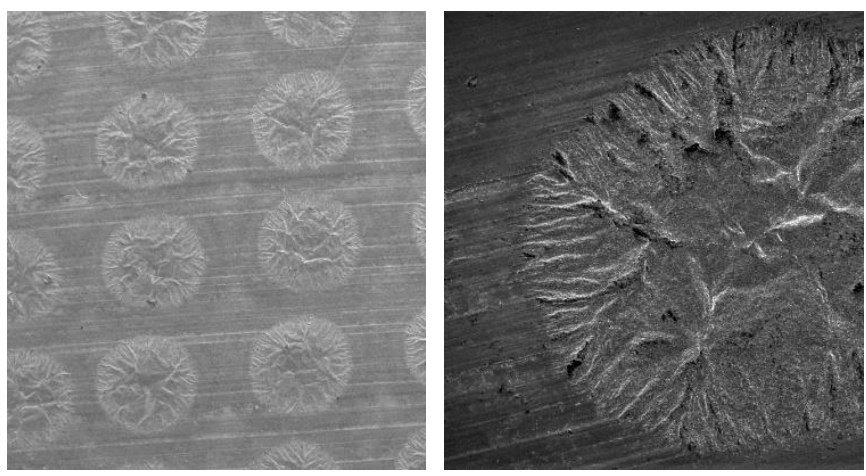
Fig. 5. Example of a modified medical implant surface (magnification $\times 100$ and $\times 500$ )

As part of the project, over 50 types of modifications were developed, and biological tests and imaging using a scanning microscope were carried out. The performed tests allowed to evaluate the effect of contact of selected cells with the material used to produce medical implants Ti6Al4V ELI. The results confirmed the growth of bone cells (osteoblasts) on the examined surfaces and noticeable changes in gene expression of the pathway responsible for osseointegration.

\section{Conclusions}

Comprehensive production technology developed (including: new construction tools, proper selection of machine kinematics, power and torque characteristics, development of a special device and selection of paths and machining parameters) allowed more than 10-fold increase in machining efficiency. Only such a holistic approach to the process can bring an above-average economic effect in the treatment of medical and technical titanium alloys.

Biological examinations of the modified implant surface (up to a version selected from several dozens of types) confirmed that due to its structuring the level of osseointegration will increase by $5 \div 10 \%$.

Higher efficiency of the manufacturing process and improvement of biocompatibility create opportunities for the dissemination of individual facial skeleton implants. The price barrier also disappears due to the fact that the cost of surgery for implanting the implant is reduced from $10 \div 12$ to $2 \div 3$ hours.

\section{REFERENCES}

1. Cichosz P. „Narzędzia skrawające”. Warszawa: PWN, 2006.

2. Grzesik W. "Podstawy skrawania materiałów konstrukcyjnych”. Warszawa: PWN, 2010.

Translation of scientific articles, their computer composition and publishing them on the website www.mechanik.media.pl by original articles in Polish is a task financed from the funds of the Ministry of Science and Higher Education designated for dissemination of science.

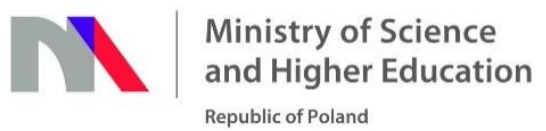

